\title{
PENGEMBANGAN PERANGKAT PEMBELAJARAN TERPADU TIPE WEBBED FOKUS IPA DENGAN TEMA "MASYARAKAT TANEYAN LANJHANG" PADA SEKOLAH DASAR DI KABUPATEN SUMENEP
}

\author{
Ike Yuli Mestika Dewi \\ Pendidikan Dasar, Pascasarjana Universitas Negeri Surabaya
}

\begin{abstract}
Abstrak
Pengembangan potensi siswa Sekolah Dasar dengan pembelajaran yang terpisah, masih memunculkan masalah yang serius dalam menghasilkan kualitas pembelajaran. Model pembelajaran yang kurang menarik dianggap sebagai hambatan utama dalam memotivasi anak dalam melaksanakan proses pembelajaran. Pengembangan perangkat pembelajaran terpadu tipe webbed dengan tema "Masyarakat Taneyan Lanjhang" dapat dijadikan sebagai solusi yang tepat dalam menjawab problem tersebut, sehingga pembelajaran terpadu tipe webbed ini dapat digunakan sebagai model pembelajaran yang bisa mendorong tumbuhnya minat belajar siswa lebih maksimal.

Penelitian ini merupakan penelitian pengembangan perangkat pembelajaran terpadu tipe webbed fokus IPA pada pokok bahasan perilaku manusia terhadap lingkungan, sumber daya alam (SDA), dan siklus air, yang menggambarkan tentang validitas (perangkat pembelajaran), kepraktisan (keterlaksanaan pembelajaran), dan keefektifan (aktivitas siswa, respon siswa, ketuntasan hasil belajar siswa, serta kendala yang dihadapi selama proses pembelajaran). Penelitian ini dilaksanakan dengan beberapa tahapan. Pertama, tahap pengembangan perangkat pembelajaran terpadu yang dilaksanakan dengan mengadopsi model pengembangan pembelajaran 4D, diantaranya Define, Design, Develop, dan Dissiminate. Kedua, tahap penelitian terhadap perangkat pembelajaran di SDN Pajagalan II Kabupaten Sumenep (ujicoba 1 dan replikasi I), dan SDN Andulang Kecamatan Gapura Kabupaten Sumenep (replikasi II).

Hasil analisis dalam penelitian ini menghasilkan beberapa temuan, antara lain: perangkat dan instrumen pembelajaran yang dikembangkan rata-rata memiliki skor yang valid dengan katagori baik. Keterlaksanaan RPP secara umum dikatagorikan baik dan aktivitas siswa menunjukkan katagori baik. Kemudian, respon siswa juga cukup positif terhadap pelaksanaan pembelajaran, sehingga hasil belajar siswa dikatagorikan tuntas dan mengalami peningkatan. Kesimpulan penelitian ini menunjukkan bahwa pengembangan perangkat pembelajaran terpadu tipe webbed fokus IPA ini dikatagorikan baik dan dapat digunakan.
\end{abstract}

Kata kunci: Pembelajaran terpadu tipe webbed, Pengembangan perangkat, Sekolah Dasar

\begin{abstract}
The potential development of elementary school students with learning separately, still poses a serious problem in producing the quality of learning. The learning model is less attractive regarded as a key constraint to motivate children to implement the learning process. Development of integrated learning device type webbed with the theme "Society Taneyan Lanjhang" can serve as an appropriate solution in addressing these problems, so that the integrated learning webbed types can be used as a learning model that could encourage the growth of student interest in learning more leverage.

This research is the development of devices integrated learning type webbed focus of IPA on the subject of human behavior on the environment, natural resources (SDA), and the water cycle, which describes the validity of (the learning), practicality (keterlaksanaan learning), and effectiveness (activity students, student responses, completeness student learning outcomes, as well as the obstacles encountered during the learning process). This research was conducted with several stages. First, the stage of development of integrated learning tools implemented by adopting a development model 4-D learning, including Define, Design, Develop, and Dissiminate. Secondly, the research phase of the learning device in SDN Pajagalan II Sumenep (trial 1 and replication I), and the District of Arch SDN Andulang Sumenep (replication II).

The results of analysis in this study resulted in some findings, among others: devices and instruments developed instructional average scores are valid with either category. Keterlaksanaan RPP generally categorized either and activities of students showed good category. Then, the students are also quite positive response to the implementation of learning, so that student learning outcomes are categorized completed and increased. The conclusion of this study indicate that the development of integrated learning device type webbed IPA focus is categorized and can be used.
\end{abstract}

Keywords: Integrated Learning webbed type, device development, Primary School 


\section{PENDAHULUAN}

Secara umum tujuan pendidikan nasional yang diamanatkan oleh Undang-Undang tersebut, mengisyaratkan tentang tujuan pendidikan yang mengarah pada upaya untuk membentuk manusia yang cerdas secara total; cerdas hati dan cerdas otak, sehingga manusia Indonesia yang ingin dibentuk melalui pendidikan yang dikembangkan adalah manusia yang cerdas seutuhnya, yaitu berimtak, berakhlak mulia, kreatif, mandiri, dan bertanggungjawab. Selain itu, pendidikan juga memiliki orientasi untuk mendorong anak didik bisa lebih aktif dalam belajar dan memahami pengalamannya secara mandiri. Sebab, belajar aktif memungkinkan siswa untuk mengejar apa yang nyata dan relevan dengan kehidupan mereka, dan mengembangkan kompetensi yang memungkinkan mereka untuk menarik makna dari pengalaman ini (Beland, 2003: 5).

Dalam konteks itu, salah satu poin penting dalam proses pendidikan tidak hanya bisa dilakukan pada salah satu aspek, melainkan terletak pada aspek yang kompleks, terutama kurikulum yang dikembangkan dan proses pembelajaran yang dilakukan, karena kurikulum dan pembelajaran merupakan rangkaian proses yang akan berdampak terhadap out put yang akan dihasilkan. Artinya, keberhasilan pendidikan tidak bisa dilepaskan dari eksistensi kurikulum yang menjadi penopang dan kegiatan pembelajaran yang menjadi bagian dari teknis pelaksanaannya, sehingga bisa membentuk anak didik yang kreatif dan kritis, seperti yang pernah diperjuangkan oleh aktivis pendidikan dalam Deklarasi Tbilisi (Djiwandono, 2013: 34), dikatakan bahwa tujuan akhir dari pendidikan adalah untuk mengajar mereka berpikir kritis yang akan memungkinkan siswa untuk menangani isuisu sosial dan lingkungan.

Dalam keterkaitan itu, upaya memperbaiki kualitas pendidikan nasional terus dilakukan oleh pemerintah, salah satunya dengan cara menerapkan konsep kurikulum 2013 dalam dunia pendidikan, sehingga upaya mencapai tujuan pendidikan nasional akan tercapai dengan baik. Penerapan kurikulum 2013 pada dasarnya merupakan bagian dari pergeseran paradigma dalam pengelolaan pendidikan yang berorientasi pada perbaikan yang berkelanjutan.

Konsep kurikulum 2013 ini tentu saja memberikan dampak yang strategis terhadap pengembangan pembelajaran yang dilakukan, terutama di kalangan sekolah dasar. Karena proses pembelajaran yang dilakukan di tingkat dasar, sebelumnya acapkali dilakukan secara konvensional dan cenderung kurang memberikan dampak yang nyata dalam mengembangkan potensi peserta didik, sehingga proses yang dilakukan kerapkali tidak menghasilkan out put yang bisa dipertanggungjawabkan. Cara belajar dan model pembelajaran memiliki posisi yang sentral dalam pendidikan, sehingga perlu dirumuskan secara sistematis dan mampu mengadopsi kondisi riil peserta didik, karena belajar sangat bergantung pada model dan cara belajar yang digunakan.

Sebagai kebijakan baru, suka atau tidak suka, kurikulum 2013 telah menjadi kebijakan yang harus diterapkan dalam dunia pendidikan. Salah satu ruh dari kurikulum 2013 adalah pembelajaran tematik terpadu (Integrated thematic instruction) yang diyakini sebagai salah satu model pembelajaran yang efektif, karena dianggap mampu mewadahi dan menyentuh secara terpadu dimensi emosi, fisik, dan akademik peserta didik di dalam kelas atau di lingkungan sekolah (Kemendikbud, 2014: 15).

Pengembangan pembelajaran tipe webbed merupakan salah satu model pembelajaran yang bisa diterapkan dalam ruang lingkup sekolah dasar, dengan tema tertentu yang dianggap relevan dengan kemampuan peserta didik di sekolah dasar, sehingga proses pembelajaran yang dilakukan bisa memberikan dampak makna yang besar terhadap pengembangan potensi anak dan sesuai dengan tujuan pendidikan yang diharapkan. Tujuan ini menjadi sangat penting dalam pengajaran (teaching), karena pengajaran merupakan tindakan yang sengaja dan beralasan. Pengajaran disengaja karena pengajaran selalu dimaksudkan untuk mencapai suatu tujuan, yakni untuk memfasilitasi siswa dalam belajar. Pengajaran itu beralasan karena apa yang diajarkan guru kepada siswa dianggap penting oleh si guru (Lorin, editor, 2010: $3)$.

Signifikansi pengembangan model pembelajaran terpadu tipe webbed pada jenjang Sekolah Dasar ini, dianggap sebagai salah satu cara dalam pengembangan dan peningkatan potensi peserta didik, karena dari sejumlah model pembelajaran terpadu, menurut Prabowo, 2003 (dalam Julianto, 2010: 4) terdapat tiga model pembelajaran yang relevan untuk dikembangkan dalam pembelajaran tingkat pendidikan dasar, terutama di Sekolah Dasar. Tiga model tersebut meliputi model keterhubungan (connected), model 
jaring laba-laba (webbed) dan keterpaduan (integrated). Tipe pembelajaran terpadu merupakan tipe pembelajaran yang dianggap sangat representatif digunakan dalam kegiatan belajar mengajar. Tipe ini menjadi salah satu tipe dari sekian tipe pembelajaran yang cukup baik dalam menata dan mengelola proses pembelajaran di kelas.

Bahkan, apabila dikaitkan dengan tingkat perkembangan anak, menurut Prabowo, 2000 (dalam Julianto, 2010: 11) pembelajaran terpadu merupakan pendekatan belajar mengajar yang melibatkan beberapa bidang studi. Pendekatan belajar seperti ini diharapkan akan memberikan pengalaman yang bermakna kepada anak didik. Arti bermakna disini, karena dalam pembelajaran terpadu diharapkan anak akan memperoleh pemahaman terhadap konsep-konsep yang mereka pelajari melalui pengalaman langsung dan menghubungkannya dengan konsep lain yang sudah mereka pahami. Pembelajaran terpadu merupakan pendekatan belajar mengajar yang memperhatikan dan menyesuaikan dengan tingkat perkembangan anak (Developmentally Appropriate Practice). Pembelajaran terpadu tipe webbed (Fogarty, 1991: 54) disebut juga sebagai kurikulum webbed (Webbed Curricula) merupakan pendekatan tematik untuk mengintegrasikan materi pelajaran. Menurut Robin Fogarty, karakteristik pendekatan tematik dalam pengembangan kurikulum ini dimulai dengan sebuah tema, misalnya tema tentang "transportasi" atau "penemuan.

Selain itu, menurut Prabowo, 2000 (dalam Daryanto, 2014: 78) pembelajaran terpadu juga merupakan pendekatan pembelajaran yang memperhatikan dan menyesuaikan pemberian konsep sesuai dengan tingkat perkembangan anak (Developmentally Appropriate Practice). Pendekatan ini berangkat dari teori pembelajaran yang menolak drill-system sebagai dasar pembentukan pengetahuan dan struktur intelektual anak).

Oleh karena itu, pembelajaran terpadu pada hakekatnya merupakan suatu sistem pembelajaran yang memungkinkan peserta didik, baik secara individu maupun kelompok, secara aktif mencari, menggali, dan menemukan konsep serta prinsipprinsip holistik, bermakna, dan otentik. Dikatakan bermakna karena dalam pembelajaran terpadu, anak akan memahami konsep-konsep yang mereka pelajari itu melalui pengamatan langsung dan menghubungkannya dengan konsep lain yang mereka pahami (Daryanto, 2014: 42).

Dalam keterkaitan itu, pembelajaran tematik terpadu tipe webbed merupakan tipe yang memiliki makna dalam proses pembelajaran dengan menggunakan tema sebagai acuan di dalamnya. Artinya, tema menjadi sentral dalam proses pembelajaran dengan model pembelajaran terpadu tipe webbed ini yang bisa memiliki keterkaitan antara satu dengan yang lainnya. Satu tema bisa menghubungkan dengan materi pelajaran lain yang terikat dan bisa dijabarkan secara berkesinambungan. Bahkan, menurut Prastowo (2013: 113) tipe webbed ini merupakan tipe pemaduan yang paling populer. Pemaduan dalam tipe ini dilakukan dengan menggunakan pendekatan tematik. Tema dapat mengikat kegiatan-kegiatan pembelajaran, baik dalam mata pelajaran tertentu maupun antar mata pelajaran.

Implementasi model pembelajaran terpadu tipe webbed dalam kegiatan belajar mengajar ditingkat sekolah dasar merupakan langkah positif dalam mengajarkan tentang "Masyarakat Taneyan Lanjhang" guna merangsang kreatifitas holistik peserta didik, apalagi tema "Masyarakat Taneyan Lanjhang" merupakan konsep masyarakat yang kental dengan nilai-nilai kearifan lokal, sehingga bisa memberikan informasi yang baru bagi peserta didik dalam mengikuti proses pembelajaran secara aktif dan kritis, sesuai dengan tujuan substansial pembelajaran untuk membentuk mental dan berfikir kritis anak didik. Taneyan Lanjhang merupakan salah satu konsep khas kehidupan komunitas masyarakat di Madura yang jarang ada dalam kehidupan masyarakat yang lain. Bahkan, Taneyan Lanjhang merupakan sebuah konsep kehidupan masyarakat yang tidak hanya menjelaskan tentang kebersamaan antara individu dengan individu yang lain, kondisi lingkungan yang tertata, dan pola keberagamaan yang kental, melainkan juga menjadi konsep utuh tentang kehidupan masyarakat yang majemuk. Oleh karena itu, masalah yang menjadi fokus kajian dalam tulisan ini dapat dirumuskan yaitu "Bagaimana kelayakan perangkat pembelajaran terpadu tipe webbed fokus IPA dengan tema "Masyarakat Taneyan Lanjhang" pada Sekolah Dasar di Kabupaten Sumenep?”

\section{METODE PENELITIAN}

Jenis penelitian ini merupakan penelitian pengembangan, yang menekankan pada pengembangan perangkat pembelajaran. Perangkat 
pembelajaran yang dikembangkan merupakan perangkat pembelajaran terpadu Sekolah Dasar yang mengacu pada pembelajaran terpadu tipe webbed fokus IPA dengan tema "Masyarakat Taneyan Lanjhang" pada sub pokok bahasan perilaku manusia terhadap lingkungan, sumber daya alam (SDA), dan siklus air. Perangkat pembelajaran tersebut meliputi silabus, rencana perangkat pembelajaran (RPP), bahan ajar siswa (BAS), lembar kegiatan siswa (LKS), dan lembar penilaian (LP).Penerapan perangkat pembelajaran menggunakan rancangan penelitian The One Group Pretest-Posttest Design, karena hanya menggunakan satu kelompok saja tanpa adanya kelompok lain sebagai pembanding (Fraenkel, 2003). Berikut merupakan tabel design penelitian one-group pretest-posttest design.

Tabel 3.1 Rancangan Penelitian One-Group Pretest-Posttest Design

$\begin{array}{ccc}\text { Pretest } & \text { Treatment } & \text { Posttest } \\ O_{1} & X & O_{2} \\ & & \text { Arikunto, (2010: 124) }\end{array}$

Keterangan:

$O_{l}=$ Uji awal (Pretest), untuk mengetahui kemampuan awal siswa sebelum perlakuan.

$\mathrm{O}_{2} \quad=\mathrm{Uji}$ akhir (Posttest), untuk mengetahui penguasaan materi setelah perlakuan.

$X=$ Perlakuan dengan menggunakan model pembelajaran terpadu tipe webbed

Penelitian ini menggunakan 3 teknik pengumpulan data, yang meliputi, Observasi (Observation), Tes, dan Angket (Kuesioner). Sementara teknis analisis data yang digunakan menggunakan beberapa instrument, yaitu ; (1) Analisis validitas perangkat pembelajaran, (2) Analisis Keterlaksanaan Pembelajaran, (3) Analisis aktivitas siswa, (4) Analisis respon siswa, (5) Analisis tes hasil belajar siswa, dan (6) Analisis Hambatan.

\section{HASIL DAN PEMBAHASAN}

Berdasarkan hasil penelitian yang dilakukan pada bagian ini,dapat dijelaskan secara komprehensif tentang hasil pengembangan perangkat pembelajaran serta implementasi perangkat dalam ujicoba 1 , replikasi I, dan replikasi II. Sebab, penelitian ini dilakukan sebagai salah satu upaya untuk mengetahui pengembangan perangkat pembelajaran terpadu tipe webbed fokus IPA dengan tema "Masyarakat Taneyan Lanjhang" yang meliputi beberapa hal, yaitu pengembangan perangkat pembelajaran tipe webbed, keterlaksanaan kegiatan pembelajaran, aktivitas siswa, respon siswa, ketuntasan belajar siswa, serta kendala yang dihadapi selama proses pembelajaran dilaksanakan. Hal itu dapat dijabarkan secara rinci sebagai berikut :

1. Validasi Perangkat Pembelajaran

Terdapat beberapa kegiatan yang dilakukan oleh peneliti sebelum melakukan penelitian, yaitu melakukan validasi terhadap perangkat pembelajaran yang akan digunakan. Validasi perangkat pembelajaran tersebut, terdiri dari Silabus, RPP, buku ajar siswa, lembar kegiatan siswa (LKS), lembar penilaian (LP), lembar pengamatan aktivitas siswa, lembar keterlaksanaan RPP, serta lembar angket respon siswa. Validasi dilakukan oleh pakar yang memiliki kompetensi di bidangnya, dengan tujuan agar perangkat pembelajaran yang dirancang bisa digunakan dalam penelitian.

Hasil validasi silabus yang dikembangkan dalam penelitian ini mencapai skor sebesar 3,6 dengan katagori baik dan sedikit revisi. Hal itu berarti bahwa silabus yang telah dibuat sudah sesuai dengan indikator dan kegiatan pembelajaran yang akan dilaksanakan di kelas, sehingga silabus dianggap telah valid dan layak untuk digunakan sebagai perangkat pembelajaran yang kemudian dapat menyusun RPP.

Hasil Rencana Pelaksanan Pembelajaran (RPP) yang dikembangkan dalam kegiatan penelitian ini, berdasarkan hasil validasi, memperoleh skor 3,58, dengan katagori baik dan sedikit revisi. Hasil tersebut dapat dijelaskan bahwa RPP yang telah dibuat oleh peneliti, sudah berpijak pada indikator pembelajaran yang akan dicapai oleh siswa, sehingga RPP menjadi valid dan layak untuk digunakan sebagai perangkat pembelajaran.

Sementara, Bahan Ajar Siswa (BAS) yang digunakan sebagai bahan dalam penelitian ini juga mendapat skor rata-rata mencapai angka 3,37 dengan katagori baik dan sedikit revisi. Skor tersebut dapat dijelaskan bahwa Bahan Ajar Siswa (BAS) yang telah dibuat dinyatakan valid dan layak untuk digunakan sebagai perangkat pembelajaran. Dengan perangkat yang disusun tersebut, dapat menjadi salah satu faktor yang bisa menentukan tercapai atau tidaknya tujuan pembelajaran, apalagi perangkat pembelajaran yang baik akan 
menentukan terhadap kualitas pembelajaran yang dilaksanakan.

Pengembangan perangkat pembelajaran yang dilakukan oleh peneliti, pada dasarnya ditekankan pada pembelajaran dengan bantuan (assisted learning) seperti yang dikembangkan oleh Vygotsky. Dalam pembelajaran yang dikembangkannya, Vygotsky menekankan pada teori scaffolding. Teori scaffolding ini erat kaitannya dengan pemagangan kognitif; pekerja yang telah berpengalaman saat bekerja dengan pemagang lazim melibatkan mereka dengan tugastugas kompleks dan mengurangi pemberian saran serta bimbingan kepada mereka secara tahap demi tahap (Nur dan Wikandari, 2008: 15).

Dalam konteks itu, teori scaffolding yang menjadi titik tekan dalam pengembangan perangkat pembelajaran dikembangkan, merupakan pengembangan perangkat pembelajaran yang dapat memberikan umpan baik kepada siswa dalam rangka pengembangan dirinya. Karena, penggunaan scaffolding dalam kehidupan sehari-hari, merupakan pemberian bantuan kepada siswa yang lebih terstruktur pada awal pelajaran dan secara bertahap mengalihkan tanggungjawab belajar kepada siswa untuk bekerja keras atas arahan dari mereka sendiri (Nur dan Wikandari, 2008: 14).

Secara praksis, teori scaffolding di kelas dilakukan dalam bentuk pengamalan nyata, yaitu ketika siswa belajar dan melakukan praktek tentang proses terjadinya hujan. Siswa dapat belajar secara bertahap tentang proses terjadinya hujan dengan menggunakan alat peraga. Pada tahap ini, siswa mendapatkan pengarahan dari guru pada awal praktik dilaksanakan. Untuk itu, pada saat siswa melakukan pengamatan terhadap proses terjadinya hujan, siswa dituntut untuk bekerja keras dalam mengamati, melakukan praktek dan mempertanggungjawabkan hasil pengamatan yang dilakukan melalui presentasi di depan kelas.

Lembar Kegiatan Siswa (LKS) yang dirancang untuk membantu proses pembelajaran, berdasarkan data dalam bab sebelumnya telah dinyatakan bahwa rata-rata skor validasinya mencapai angka $100 \%$, sehingga dikategorikan baik dengan sedikit revisi. Hasil itu tentu saja dapat dijelaskan bahwa lembar kegiatan siswa (LKS) yang telah dibuat, layak digunakan sebagai instrumen pembelajaran. Demikian pula halnya dengan validasi Lembar Penilaian (LP) siswa, bahwa skor validasi lembar penilaian (LP) mencapai angka 3,38 dengan kategori baik dengan sedikit revisi, sehingga layak untuk digunakan sebagai instrumen pembelajaran.

2. Keterlaksanaan Kegiatan Pembelajaran

Berdasarkan data hasil pengamatan keterlaksamaan kegiatan pembelajaran terpadu, dari sejumlah aspek yang diamati dikatagorikan baik, yaitu. Pertama, pada ujicoba 1 meliputi kegiatan pelaksanaan pendahuluan (3.4), kegiatan pelaksanaan [inti] (3.25), kegiatan penutup (3.4), pengelolaan waktu (3.6), dan suasana kelas (3.6). Kedua, replikasi I meliputi kegiatan pelaksanaan pendahuluan (3.9), kegiatan pelaksanaan [inti] (3.7), kegiatan penutup (3.75), pengelolaan waktu (3.9), dan suasana kelas (3.87). Ketiga, replikasi II meliputi kegiatan pelaksanaan pendahuluan (3.9), kegiatan pelaksanaan [inti] (3.8), kegiatan penutup (3.9), pengelolaan waktu (3.9), dan suasana kelas (4).

Berdasarkan data hasil pengamatan, baik dalam ujicoba 1, replikasi I, dan replikasi II, dapat digambarkan bahwa keterlaksanaan pembelajaran (RPP) dalam setiap pertamuan yang dilakukan, mengalami peningkatan yang positif. Hal itu karena kendala yang terjadi pada pada saat ujicoba 1 , tidak dilakukan lagi pada saat replikasi I dan replikasi II. Kemudian, berdasarkan saran pengamat dan guru pada saat ujicoba 1, maka keterlaksanaan RPP dilakukan perbaikan untuk meningkatkan hasil yang maksimal. Sebab, dengan peningkatan keterlaksanaan pembelajaran (RPP), menunjukkan bahwa siswa telah dapat mempelajari konsepkonsep dengan baik, apabila berada dalam ZPD (Zone of Proximal Development). Karena dengan $\mathrm{ZPD}$, siswa dalam memecahkan masalah, akan mendapatkan bantuan dari guru yang bersangkutan. Dengan bantuan tersebut, siswa akan dapat mengerjakan setiap tugas yang memiliki tingkat kerumitan di atas tingkat perkembangan pengetahuan yang dimiliki siswa. Oleh karena itu, peningkatan keterlaksanan pembelajaran (RPP) siswa sangat berdampak tehadap perkemangan pengetahuan siswa.

3. Aktivitas Siswa dalam Proses Pembelajaran

Berdasarkan hasil pengamatan aktivitas siswa dinyatakan bahwa aktivitas siswa selama mengikuti kegiatan pembelajaran cukup aktif, baik pada saat ujicoba I, replikasi I, dan replikasi II. Kategori yang meliputi: mendengarkan/memperhatikan penjelasan guru, berdiskusi/tanya jawab antara siswa dan guru (saling interaksi), membaca buku siswa dan mengerjakan LKS, mendengarkan/memperhatikan 
penjelasan teman, melakukan pengamatan/penyelidikan, menyimpulkan hasil percobaan, mempresentasikan hasil percobaan, dan merangkum pelajaran.

Dari berbagai kategori yang diamati, skor tertinggi terjadi pada kategori melakukan pengamatan/penyelidikan yang mencapai $26.2 \%$ (ujicoba 1), 27.2\% (replikasi I), dan 29\% (replikasi II) dengan kategori aktif. Hal itu relevan dengan tingkat Sekolah Dasar yang menyatakan bahwa siswa SD, memliki rasa ingin tahu yang tinggi, sementara kegiatan praktek memang banyak disenangi oleh siswa. Hal itu relevan dengan teori pembelajaran yang dikembangkan oleh Albert Bandura yang menekankan pada proses belajar melalui pengalaman atau pengamatan. Apalagi teori pembelajaran yang dikembangkan oleh Bandura, memang menekankan pada masalah perilaku atau pemodelan.

Sedangkan kategori dengan skor terendah adalah kategori yang mempresentasikan hasil percobaan, yang hanya mencapai $2.5 \%$ (ujicoba 1 ), $2.1 \%$ (replikasi I), dan 3\% (replikasi II) dengan kategori siswa kurang aktif yang disebabkan karena tidak semua siswa mendapatkan kesempatan yang sama dalam mempresentasikan hasil pengamatannya, melihat waktu pengelolaan pembelajaran di kelas. Hal itu relevan dengan teori Albert Bandura, yang menekankan pada empat elemen penting, yaitu atensi, retensi, reproduksi dan motivasi. Pada aspek atensi, siswa mendengarkan dan memberikan perhatian secara cermat terhadap penjelasan yang disampaikan oleh guru. Kemudian, aspek retensi, siswa dapat meningat kembali yang didengar dari guru dan dibaca dalam buku siswa. Sementara aspek reproduksi, siswa dapat melakukan kegiatan mempraktekkan apa yang diajarkan oleh guru dalam kegiatan praktik yang diberikan oleh guru. Persentase rata-rata instrumen pengamatan aktivitas siswa terhadap keterlaksanaan pembelajaran terpadu tipe webbed untuk ujicoba 1 adalah $94.67 \%$, replikasi I adalah $97.07 \%$, dan replikasi II adalah 96,10\%. Menurut Borich (1994: 385) menyatakan bahwa instrumen dikatakan reliable apabila nilai reliabilitasnya mencapai $\geq$ $75 \%$. Dengan demikian, instrumen pengamatan aktivitas siswa terhadap keterlaksanaan pembelajaran terpadu tipe webbed termasuk kategori baik dan layak digunakan sebagai lembar pengamatan.

4. Respon Siswa Terhadap Proses Pembelajaran
Berdasarkan data persentase respon siswa terhadap pembelajaran terpadu tipe webbed, baik dari aspek proses pembelajaran, minat terhadap pembelajaran, metode dan perangkat pembelajaran. Respon siswa terhadap aspek proses pembelajaran rata-rata mencapai 96.8, yang meliputi materi pelajaran, buku siswa, LKS, cara mengajar, kegiatan praktikum. Untuk aspek minat terhadap pembelajaran rata-rata mencapai 95.3, yang berkaitan dengan minat untuk mengikuti kegiatan pembelajaran berikutnya. Kemudian, aspek metode dan perangkat mencapai mencapai 93.7, yang meliputi bahasa yang digunakan, penampilan bahan bacaan, dan ilustrasi gambar buku siswa. Oleh karena itu, data di atas menjelaskan bahwa pembelajaran terpadu tipe webbed yang dikembangkan oleh peneliti dianggap telah mendapatkan respon yang baik dari kalangan siswa, sehingga siswa merasa tertarik dengan proses pembelajaran yang dilakukan. Ketertarikan siswa tersebut menunjukkan bahwa pembelajaran yang dilakukan telah mampu membuat siswa termotivasi untuk mengikuti pembelajaran terpadu. Motivasi merupakan unsur paling penting dalam pengajaran yang efektif atau pengajaran yang berhasil (Nur, 2003: 2)

\section{Ketuntasan Hasil Belajar}

Ketuntasan hasil belajar yang dilakukan dalam kajian ini, mengacu pada tiga aspek hasil ketuntasan. Pertama, ketuntasan hasil belajar pengetahuan (kognitif). Sebagaimana telah lazim dilakukan dalam proses pembelajaran yang dilakukan, tes merupakan rangkaian penting dalam proses pembelajaran yang dilakukan. Tujuan utama tes (lembar penilaian) yang dilakukan adalah untuk mengetahui tentang tingkat ketercapaian tujuan pembelajaran yang dilakukan. Dalam penelitin ini, peneliti melaksanakan beberapa kali tes, yaitu pretest (ujian awal) dan posttest (ujian akhir). Hasil pretest dan posttest yang dilakukan dalam penelitian ini mengalami peningkatan yang cukup positif, baik yang dilakukan pada saat ujicoba 1, replikasi 1 dan replikasi II. Pada kegiatan ujicoba 1, nilai pretest nilai rata-rata mencapai 17.2, kemudian pada posttest dengan nilai rata-rata mencapai 84. Pada replikasi I, pretest dengan nilai rata-rata mencapai 17 dan posttest dengan nilai rata-rata mencapai 85 , kemudian pada replikasi II, untuk pretest dengan nilai rata-rata 17,5 dan posttest dengan nilai rata mencapai 85 . Berdasarkan data hasil belajar yang diperoleh dari uji akhir (posttest) secara individual dinyatakan tuntas dan 
secara klasikal dinyatakan tuntas juga. Tes hasil belajar pengetahuan (kognitif yang berupa lembar penilaian (LP) merupakan tes yang mengukur aspek pengetahuan $(\mathrm{C} 1)$, pemahaman $(\mathrm{C} 2)$, penerapan (C3), analisis (C4), sintesis (C5), dan penilaian (C6).

Dalam konteks itu, peran pengetahuan (kognitif) dalam proses pembelajaran semacam itu, menjadi tolok ukurnya. Perkembangan pengetahuan (kognitif) pada masa anak usia sekolah dasar, merupakan masa-masa penting dalam proses pembelajaran yang harus mendapatkan perhatian serius. Jean Piaget merupakan tokoh penting yang fokus mengembangkan teori perkembangan pengetahuan (kognitif) dalam proses belajar. Menurut Piaget bahwa untuk memahami gagasan tentang belajar yang memadai, kita pertamapertama harus menjelaskan bagaimana individu bisa mengkonstruksi dan menciptakan, bukan hanya bagaimana dia mengulangi dan meniru (Gredler, 2011: 322).

Kedua, ketuntasan penilaian keterampilan (psikomotor). Berdasarkan hasil analisis penilaian keterampilan (psikomotor) siswa diseutkan bahwa tingkat keterampilan siswa berkisar antara 75-100. Hal ini ditunjukkan dengan rata-rata nilai keterampilan yang mencapai 88 (ujicoba1), 89 (replikasi I), dan 87 (replikasi II). Penilaian keterampilan (psikomotor) merupakan penilaian yang mengukur beberapa aspek, diantaranya imitasi $(\mathrm{P} 1)$, manipulasi (P2), presisi (P3), dan artikulasi (P4).

Ketiga, ketuntasan penilaian sikap (afektif).Berdasarkan hasil analisis penilaian sikap (afektif) menunjukkan bahwa pada setiap aspek yang diukur sebagian mengalami kenaikan pada setiap pertemuan. Rata-rata penilaian sikap pada ujicoba 1 mencapai 85,7 dengan hasil penilaian sikap yang terendah mencapai 75,6 sampai nilai sikap yang tertinggi mencapai 100. Rata-rata penilaian sikap pada replikasi I mencapai 90 dengan hasil penilaian sikap yang terendah mencapai 76 sampai nilai sikap yang tertinggi mencapai 100. Rata-rata penilaian sikap pada replikasi II mencapai 90 dengan hasil penilaian sikap yang terendah mencapai 81 sampai nilai sikap yang tertinggi mencapai 96.

Kelima, rekap penilaian pengetahuan (kognitif), keterampilan (psikomotor), dan sikap (afektif). Berdasarkan hasil rekapitulasi penilaian pengetahuan (kognitif), keterampilan (psikomotor), dan sikap (afektif) pada bab sebelumnya menyatakan bahwa ketuntasan hasil belajar siswa ujicoba 1 mencapai antara 77.2 s.d 99 dengan ratarata nilai 85 , replikasi I (tabel 4.24) mencapai antara 75 s.d 100 dengan rata-rata nilai 87, dan replikasi II mencapai antara 78 s.d 97 dengan ratarata nilai 87. Pencapaian tersebut menunjukkan bahwa seluruh siswa tuntas dalam proses pembelajaran baik dari ketuntasan hasil belajar secara individu maupun klasikal. Sebab, berdasarkan hasil ujicoba 1 di atas, rata-rata ketuntasan hasil belajar di atas $75 \%$. Sebab, ketuntasan belajar siswa terhadap model pembelajaran terpadu tipe webbed dengan tema "Masyarakat Taneyan Lanjhang" pada siswa SD dikatakan tuntas,apabila memenuhi KKM $75 \%$.

Hal itu terjadi karena dari aspek keterlaksanaan pembelajaran berjalan dengan baik, sehingga berdampak terhadap aspek aktivitas siswa yang positif. Ketercapaian dua aspek tersebut, pada gilirannya berpengaruh terhadap hasil belajar siswa. Kemudian, dilihat dari hasil pretest, siswa belum tuntas, dan setelah siswa mendapatkan pembelajaran, akhirnya pada saat posttest, seluruh siswa tuntas dalam proses pembelajaran, baik secara individu maupun klasikal. Oleh karena itu, pengembangan perangkat pembelajaran dalam kajian ini telah memenuhi criteria perangkat pembelajaran yang telah ditetapkan, seperti dijelaskan oleh Nieveen (1999: 127), yang meliputi kevalidan (validity), kepraktisan (practicality) dan kefektifan (effectiveness).

\section{PENUTUP}

Berdasarkan penelitian yang telah dilaksanakan, perangkat pembelajaran yang dilakukan pada penelitian ini, berorientasi pada model pembelajaran terpadu tipe webbed fokus IPA dengan tema "Masyarakat Taneyan Lanjhang", terdapat beberapa temuan penelitian. Pertama, validitas perangkat pembelajaran dengan model pembelajaran terpadu tipe webbed fokus IPA dengan tema "Masyarakat Taneyan Lanjhang", baik silabus, RPP, BAS, LKS dan LP dainggap valid dan layak untuk digunakan. Kedua, kepraktisan perangkat pembelajaran diambil dari data pengamatan keterlaksanaan pembelajaran dalam setiap pertemuan. Keterlaksanaan pembelajaran dengan model pembelajaran terpadu tipe webbed berjalan dengan baik dan ada peningkatan dalam pengelolaan pembelajaran yang dilakukan oleh guru pada setiap pertemuan pelaksanaan pembelajaran baik pada ujicoba 1 , replikasi I, dan 
replikasi II. Ketiga, keefektifan dari perangkat pembelajaran yang dikembangkan dapat dilihat dari data aktivitas siswa, respon siswa, tes hasil belajar siswa, dan hambatan/kendala yang dihadapi saat penelitian berlangsung, baik aktivitas siswa, respon siswa, hasil belajar siswa dapat dikatagorikan baik. Oleh karena itu, perangkat pembelajaran terpadu tipe webbed fokus IPA dengan tema "Masyarakat Taneyan Lanjhang", dinyatakan layak berdasarkan beberapa indikator (keterlaksanaan pembelajaran, aktivitas siswa, respon siswa, dan tes hasil belajar) yang telah dicapai.

\section{DAFTAR PUSTAKA}

Arikunto, Suharsimi. (2010). Prosedur Penelitian, Suatu Pendekatan Praktek. Jakarta: PT Rineka Cipta.

Beland, Kathy. (2003). Character education: Providing A Meaningful Academic Curriculum. Washington: CEP (Character Education Partnership).

Borich, G. D. (1994). Obsvervation Skill For Effective Teaching. New York: Mc Millan Publishing Company

Djiwandono, Patrisius Istiarto.Critical Thinking Skill for Language Students. Teflin. Vol 24 No. 1 January 2013. ISSN 0215-773 X. pp. 34.

Fogarty, Robin. (1991). How to Integrate The Curriula. USA: Publishing Inc.

Gredler, Margaret E. (2011), Learning and Instruction: Teori Aplikasi. Jakarta : Kencana Prenada Media Group.

Julianto. (2010). Kajian Teori dan Implementasi Model Pembelajaran Terpadu Dalam Pembelajaran Di Kelas. Surabaya: Unesa University Press.

Kemendikbud. (2014). Materi Pelatihan Guru Implementasi Kurikulum 2013 Tahun 2014. Jakarta: Kemendikbud.
Lorin, V Anderson dan David. (2010). Kerangka Landasan untuk Pembelajaran, Pengajaran dan Asesmen. Yogjakarta: Pustaka Pelajar.

Nieveen, Nienke. (1999). "Prototyping to Reach Product Quality". In collaboration with Interuniversitair Centrum voor Onderwijskundig Onderzoek (ICO) (Ed). Design Approaches And Tools In Education And Training, 125-135. SpringerScience+Business Media, B.V.

Nur, Mohamad. (2003). Pemotivasian Siswa Untuk Belajar. Surabaya: Universitas Negeri Surabaya (Pusat Sain dan Matematika Sekolah). 